\title{
L X T Analysis of Yield Characters in Chickpea (Cicer arietinum L.) under Rice Based Cropping System
}

\author{
P.L. Johnson*, R.N. Sharma and H.C. Nanda \\ Department of Genetics and Plant Breeding, Indira Gandhi Krishi Vishwavidyalaya, \\ Raipur 492 012, Chhattisgarh, India \\ *Corresponding author
}

\section{A B S T R A C T}

Line $\mathrm{x}$ Tester analysis mean sum of square due to genotypes was highly significant for all the traits in $E_{1}, E_{2}$ and $E_{3}$. Analysis of variance for combining ability revealed that the

Keywords

L $\mathrm{x}$ T analysis, Chickpea, Rice based Cropping System

Article Info

Accepted:

12 May 2019

Available Online:

10 June 2019 variance due to gca were highly significant for all the characters in all the environments except for days to maturity in $E_{1}$, plant height and primary branches plant ${ }^{-1}$ in $E_{1}, E_{2}$ and $E_{3}$, secondary branches, seed yield and harvest index in $E_{2}$ and $E_{3}$, pods plant ${ }^{-1}$ in $E_{1}$ and $E_{2}$, biological yield plant ${ }^{-1}$ in $\mathrm{E}_{2}$ and protein content in $\mathrm{E}_{1}$. Similarly variance due to sca were highly significant for all the characters in all the environments except days to maturity in $E_{1}$, plat height, primary branches plant ${ }^{-1}$ and secondary branches plant ${ }^{-1}$ in $E_{3}$, seed yield plant $^{-1}$ in $E_{2}$ indicated the importance of both additive and non-additive gene effect in their expression. Per se performance seed yield plant ${ }^{-1}$ is the ultimate and most important traits presented in table. In the present investigations, the degree of heterosis for seed yield varied considerably. Out of 21 crossed 2 crosses (JG 130 x JG 97 and JG 315 x JG 97) exhibited significant positive mid and better parents heterosis in all three environments. However, the highest mean value was sown JG 130 x JG 97(71.30 $\mathrm{g} \mathrm{plant}^{-1}$ ) in $\mathrm{E}_{1}, 66.55 \mathrm{~g}$ plant $^{-1}$ in $E_{2}$ and $40.55 \mathrm{~g} \mathrm{plant}^{-1}$ in $E_{3}$ for high seed yield should be utilized for future hybridization programme

\section{Introduction}

Chickpea [Cicer arietinum (L.) $2 n=2 x=16$ ] belongs to genus Cicer, tribe Cicereae, family Fabaceae, and subfamily Papilionaceae. It is commonly called gram, bengal gram or garbanzo bean, is the most important cool season food grain legume in the world after common bean (Phaseolus vulgaris L.) and pea (Pisum sativum L.). Chickpea is the world's third most important food legume crop grown as rainfed in cool and dry climate in semi-arid regions. During the last few decades, due to increasing demand of the food for world's growing population depend to a large extent on the conservation and use of world's remaining plant genetic resources. Chickpea covers about 11.7 million ha area and 9.3 million tones production in over 45 countries of the world. India is the largest chickpea producer accounting a share of about $67 \%$ in global chickpea production with about 9.93 million ha area, 9.53million tones production and productivity of $960 \mathrm{~kg} / \mathrm{ha}$. 
Distribution of chickpea in six states viz., Madhya Pradesh, Rajasthan, Maharashtra, Uttar Pradesh, Karnataka and Andhra Pradesh together contribute $90.2 \%$ of the production and $90.8 \%$ of the area of the country. Chhattisgarh covers 0.276 million ha area with production 0.213 million tones and productivity of $771 \mathrm{~kg} \mathrm{ha} \mathrm{ha}^{-1}$. (Project Coordinators Report, 2014-15). Yield is a complex polygenic trait and is influenced by large number of quantitative and qualitative traits. There may not be genes for yield per $s e$, in spite there could be genes, which govern the inheritance of yield characters. Information regarding association between yield and yield characters are required in any breeding programme.

\section{Materials and Methods}

The experimental material comprised viz. seven lines viz., Vaibhav, Indira Chana-1, JG 315, JG 11, JG 14, JG 16, JG 130 of agronomic base and three testers JG 97, ICCV 96029 and ICCV 96030 for early maturity were crossed as per Line $\mathrm{x}$ Tester mating design fashion (Kempthorn, 1957) to develop $21 \mathrm{~F}_{1}$ during 2014-15. These $\mathrm{F}_{1}$ along with their parents were evaluated two replication in one row plot during 2015-16. Under following three rice based cropping system viz. $\mathrm{E}_{1}$ : Cropping System I: after harvest of early rice variety (Danteshwari) CS-I, E Cropping System II: after harvest of medium rice variety (Mahamaya). CS-II, $\mathrm{E}_{3 \text { : }}$ Cropping System III: after harvest of late rice variety (Dubraj) CS-III. The row to row and plant to plant spacing $30 \times 10 \mathrm{~cm}$ maintained at Research cum Instructional farm, Department of Plant Breeding and Genetics, Indira Gandhi Agricultural University, Raipur The recommended packages of practices were adopted to raise the normal crops. Observations on metric traits where recorded on single plant basis on five randomly selected competitive plant of each genotypes from each replication in each cropping system were as observation on days to $50 \%$ flowering, days to maturity, plant height $(\mathrm{cm})$, number of primary branches plant ${ }^{-1}$, pods plant $^{-1}$, Biological yield plant $^{-1}(\mathrm{~g})$, harvest index (\%), 100 seed weight $(\mathrm{g})$, Seed yield plant $^{-1}(\mathrm{~g})$, seed volume $\left(\mathrm{ml} \mathrm{seed}^{-1}\right)$, hydration capacity $\operatorname{seed}^{-1}(\mathrm{~g})$, hydration index, swelling index and protein content $(\%)$ were recorded on plot basis as per the chickpea descriptor developed by ICRISAT-IBPGR- ICARDA (1993). Jinks (1983) outlined the importance of heterosis breeding in self-pollinated crops to extract pure breeding lines equalling or outperforming the best F1s. Therefore, the present investigation was made to generate information on heterosis for yield and physiological attributes in chickpea. Rojas and Sprague (1952) concluded that the information on the SCA would often be lower in predictive value than the information on the gca. Kempthorne (1957) proposed this concept in line $\times$ tester analysis.

\section{Results and Discussion}

\section{Analysis of variance}

The analysis of variance for line $\mathrm{x}$ tester analysis for the traits under study has been presented in Table 1). The mean sums of square due the genotypes significant of the mean square for parents $v s$. hybrid are taken to indicate presence of heterosis. Although this method is statistically valid, conclusion regarding heterosis may not be reliable and useful. It is a comparison of mean of the parents as a group with the mean of crosses as group. Significant could result even when mean of crosses as a group is smaller than mean of parental line as a group. The highly significant variance due to parent $v s$ crosses recorded for all the characters in all three environments except days to $50 \%$ flowering in $\mathrm{E}_{1}$, days to $50 \%$ flowering, harvest index and seed yield plant ${ }^{-1}$ in $E_{2}$, days to $50 \%$ 
flowering, plant height and secondary branches plant ${ }^{-1}$ in $E_{3}$. Mean square due to line and tester were found to be significant for all the traits in all the environments except days to maturity in all the Environments. Primary branches plant ${ }^{-1}$ in $E_{1}$ and $E_{3}$, secondary branches plant $^{-1}$ and yield plant ${ }^{-1}$ in $E_{2}$ and protein content in $\mathrm{E}_{3}$. Hence, its indicated that line does not appear to behave consistently over different tester in the respective environments.

\section{Analysis of variance for combining ability}

Analysis of variance for combining ability (Table 2) revealed that the variance due to gca were highly significant for all the characters in all the environment except for days to maturity in $E_{1}$, plant height and primary branches plant ${ }^{-1}$ in $E_{1}, E_{2}$ and $E_{3}$, secondary branches, seed yield and harvest index in $\mathrm{E}_{2}$ and $E_{3}$, pods plant ${ }^{-1}$ in $E_{1}$ and $E_{2}$, biological yield plant ${ }^{-1}$ in $E_{2}$ and protein content in $E_{1}$. Similarly variance due to sca were highly significant for all the characters in all the environments except days to maturity in $\mathrm{E}_{1}$, plant height, primary branches plant $^{-1}$ and secondary branches plant ${ }^{-1}$ in $\mathrm{E}_{3}$, seed yield plant $^{-1}$ in $E_{2}$ indicating importance of both additive and non-additive gene effect in their expression. Result of the analysis revealed that the variance due to gca was lower than sca variance for all most all the characters in all the environments except protein content in $\mathrm{E}_{2}$, primary branches plant ${ }^{-1}$ and secondary branches plant $^{-1}$ in $E_{3}$, suggesting the predominance of non-additive gene action controlling these characters. Dominance genetic variance was larger than additive genetic variance for the characters, these result are supported by ratio of variance to general to specific combining ability $\left(\sigma^{2}\right.$ gca/ $\sigma^{2}$ sca) which was smaller than unity and by the degree of dominance $\left(\sigma^{2} \mathrm{D} / \sigma^{2} \mathrm{~A}\right)$ which take values greater than unity. Therefore, it applied that the inheritance of these traits was controlling by a preponderance of nonadditive gene effect. Such types of gene action clearly indicated that selection of superior plant for these characters should be postponed to latter generation where these characters can be improved by making selection among the recombinants which the segregating population. As the ratio of gca: sca variance more than unit recorded for protein content in $\mathrm{E}_{2}$, primary branches plant ${ }^{-1}$ and secondary branches plant ${ }^{-1}$ in $\mathrm{E}_{3}$ further supported by finding degree of dominance and heritability indicated the role of additive genetic variance in their expression. Hence, direct selection for the characters would be advantageous in isolating chickpea genotypes of more protein content and more primary branches and secondary branches. These finding are in general agreement with the finding of Verma and Waldiya (2010), Monpara and Dhamelia (2013).

High estimate of heritability in narrow sense were observed for secondary branches plant ${ }^{-1}$ in $\mathrm{E}_{1}, \mathrm{E}_{2}$ and $\mathrm{E}_{3}$, days to $50 \%$ flowering in $\mathrm{E}_{1}$, primary branches plant ${ }^{-1}$ in $\mathrm{E}_{2}$ and $\mathrm{E}_{3}$, harvest index in $E_{2}$ and $E_{3}$,swelling index in $E_{1} E_{2}$ and $\mathrm{E}_{3}$ and protein content in $\mathrm{E}_{2}$. This supported the involvement of both additive and non-additive gene effects. Rest of the character showed moderates to low narrow sense heritability over the environments. Similar finding were reported by Khan et al., (2006), Gupta et al., (2007), Verma and Waldiya (2010), Bhatt et al., (2013) and Monparaand Gaikwad (2014).

\section{General combining ability}

\section{Seed yield plant ${ }^{-1}$}

For seed yield parents JG 14 and JG 16 inall the three environments. ICCV 96029 in $\mathrm{E}_{1}$ and $E_{2}$ and ICCV 96030 in $E_{1}$ exhibited the desirable gca for the traits parents JG 14 in $\mathrm{E}_{1}$ and $E_{2}$ and JG 16 in $E_{3}$ have been considered as the best general combiners 


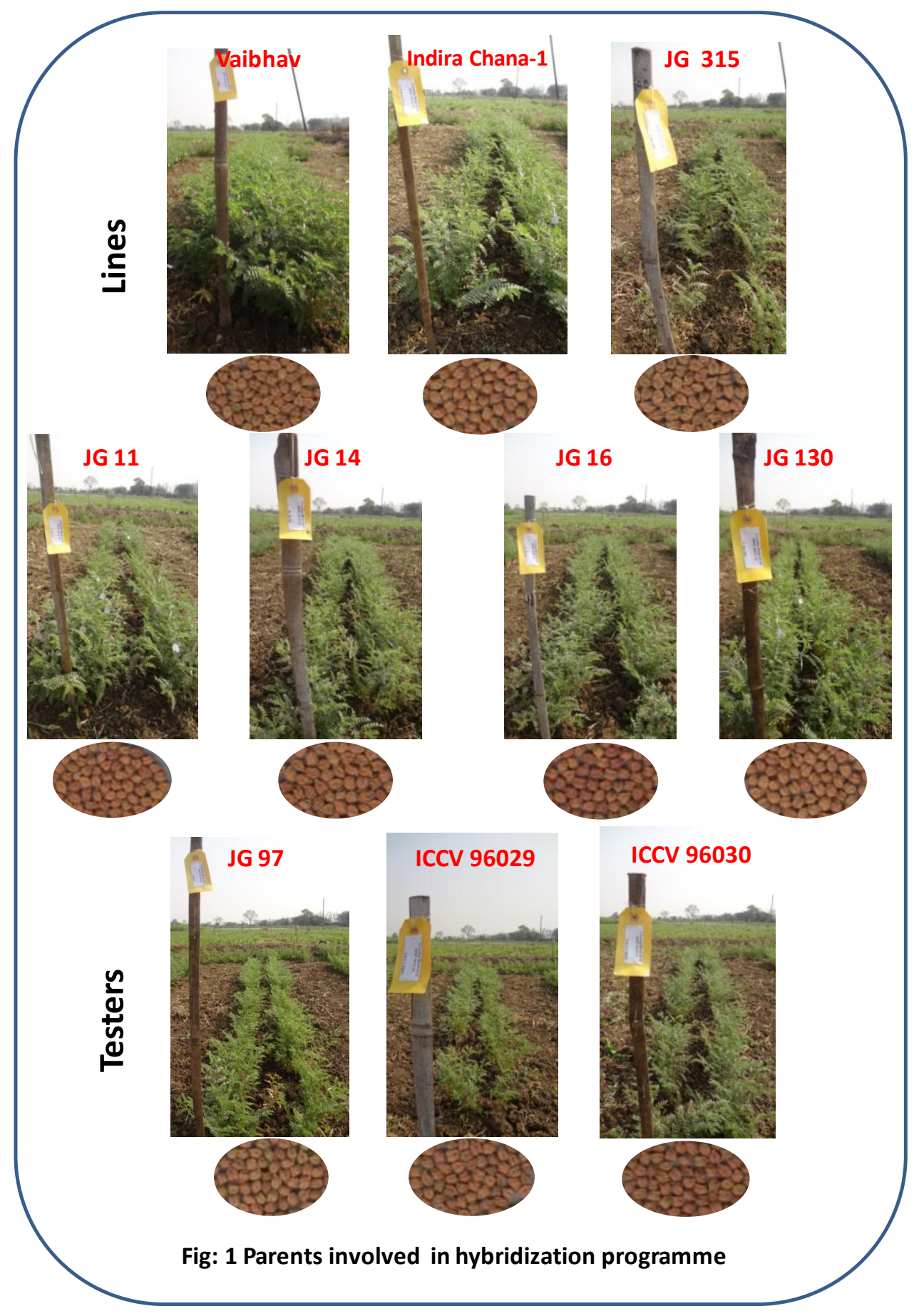




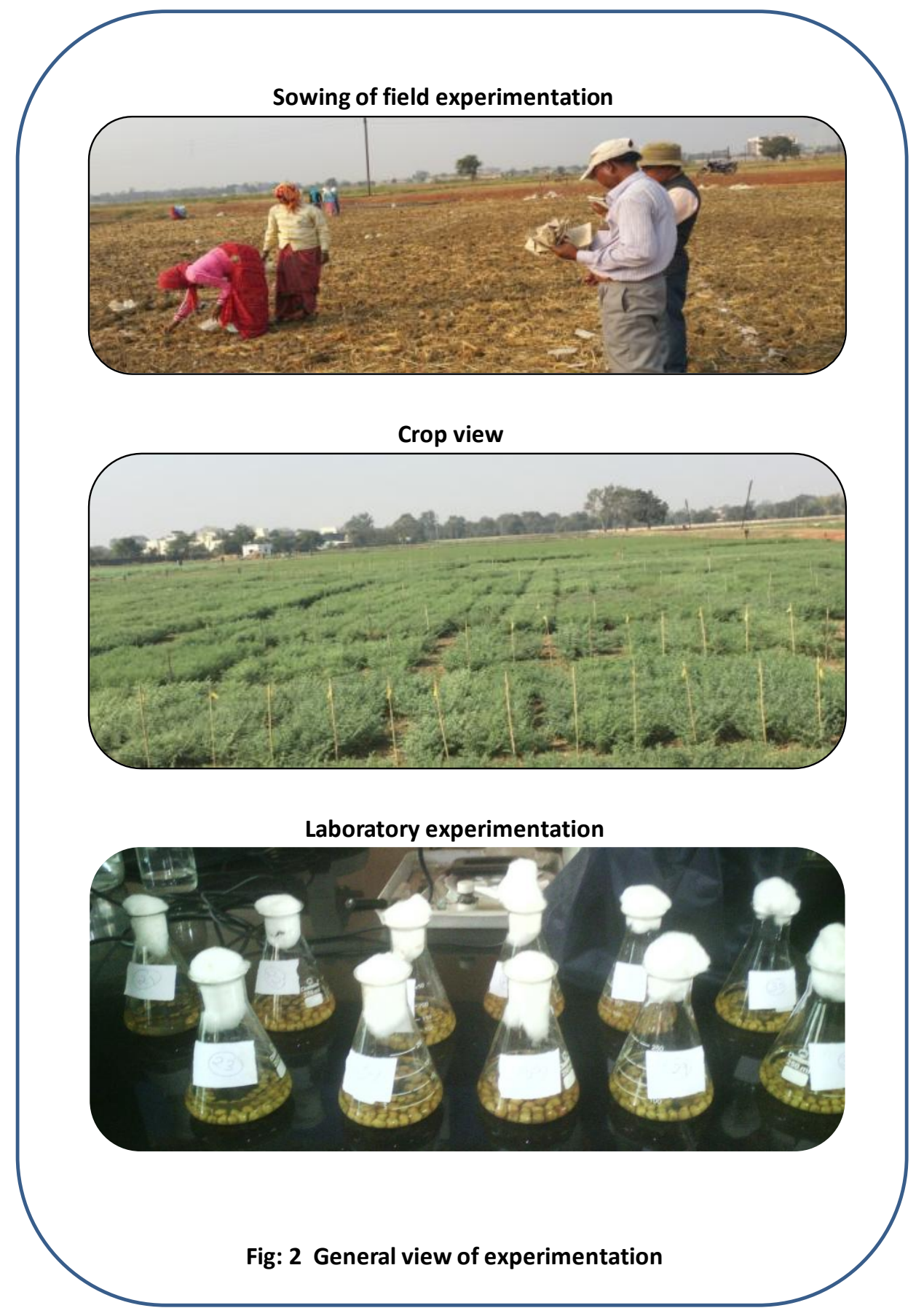




\section{Int.J.Curr.Microbiol.App.Sci (2019) 8(6): 1640-1651}

Table.1 Analysis of variance for $\mathrm{L} x \mathrm{~T}$ for yield, its attributes and quality characters under $\mathrm{E}_{1}, \mathrm{E}_{2}$ and $\mathrm{E}_{3}$ in chickpea

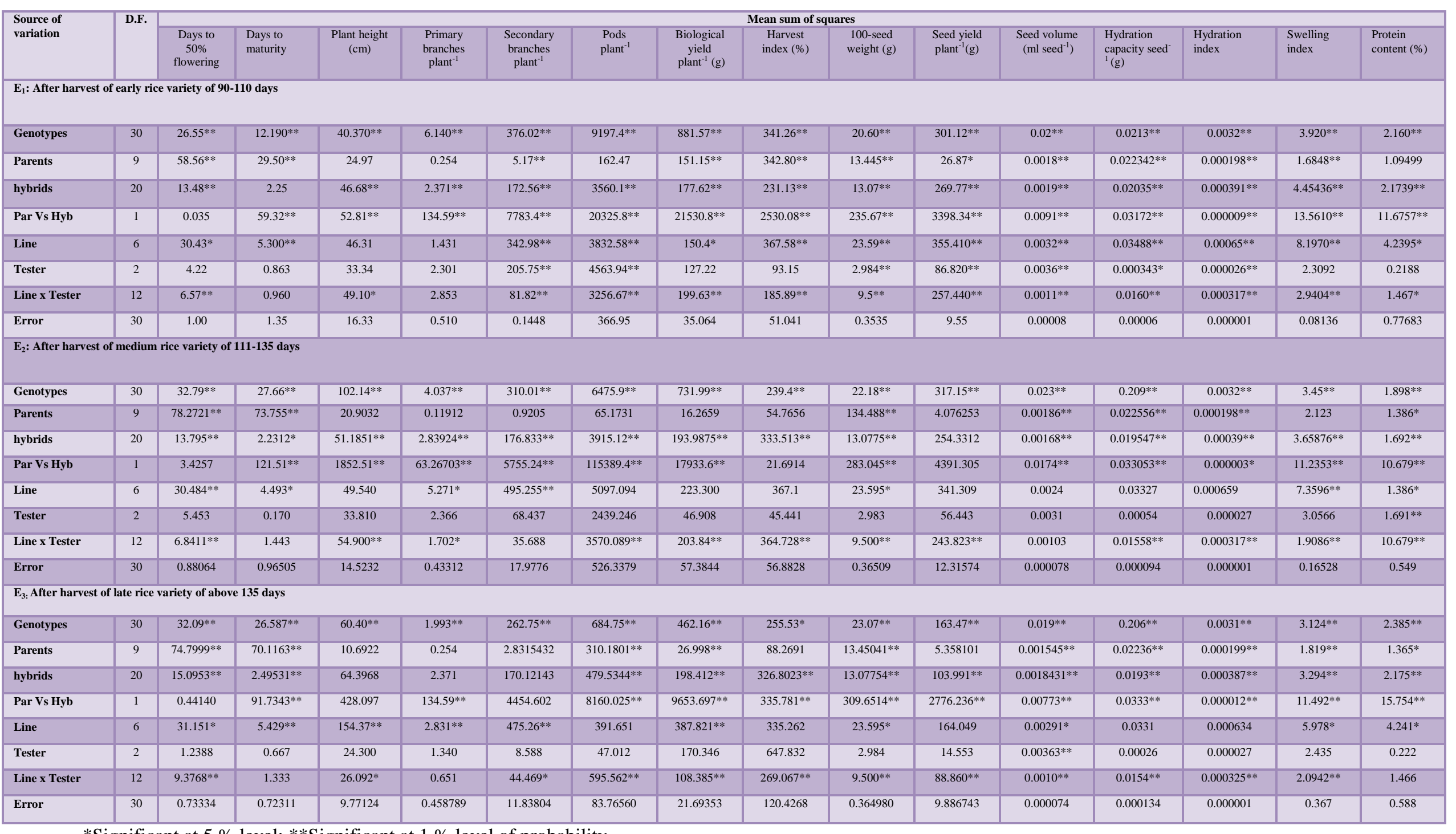

*Significant at $5 \%$ level; **Significant at $1 \%$ level of probability 
Table.2 Analysis of variance for combining ability and genetic components for seed yield, its attributes and quality characters under $\mathrm{E}_{1}, \mathrm{E}_{2}$ and $\mathrm{E}_{3}$ in chickpea

\begin{tabular}{|c|c|c|c|c|c|c|c|c|c|c|c|c|c|c|c|c|}
\hline $\begin{array}{l}\text { Source of } \\
\text { variation }\end{array}$ & D.F. & $\begin{array}{c}\text { Days to } \\
50 \% \\
\text { flowering }\end{array}$ & $\begin{array}{l}\text { Days to } \\
\text { maturity }\end{array}$ & $\begin{array}{c}\text { Plant } \\
\text { height }(\mathrm{cm})\end{array}$ & $\begin{array}{c}\text { Primary } \\
\text { branches } \\
\text { plant }^{-1}\end{array}$ & $\begin{array}{c}\text { Secondary } \\
\text { branches } \\
\text { plant }^{-1}\end{array}$ & $\begin{array}{l}\text { Pods } \\
\text { plant }^{-1}\end{array}$ & $\begin{array}{c}\text { Biological } \\
\text { yield } \\
\text { plant }^{-1}(g)\end{array}$ & $\begin{array}{c}\text { Harvest } \\
\text { index (\%) }\end{array}$ & $\begin{array}{c}\text { 100-seed } \\
\text { weight (g) }\end{array}$ & $\begin{array}{l}\text { Seed yield } \\
\text { plant }^{-1}(\mathrm{~g})\end{array}$ & $\begin{array}{c}\text { Seed volume } \\
\left(\mathrm{ml} \mathrm{seed}^{-1}\right)\end{array}$ & $\begin{array}{l}\text { Hydration } \\
\text { capacity seed } \\
{ }_{1}(\mathrm{~g})\end{array}$ & $\begin{array}{l}\text { Hydration } \\
\text { index }\end{array}$ & $\begin{array}{l}\text { Swelling } \\
\text { index }\end{array}$ & $\begin{array}{l}\text { Protein } \\
\text { content } \\
(\%)\end{array}$ \\
\hline \multicolumn{17}{|l|}{$\mathrm{E}_{1}$ : CSI } \\
\hline GCA & 9 & $58.56^{* * *}$ & $29.50^{* *}$ & 24.97 & 0.254 & $5.17^{* *}$ & 162.47 & $151.15^{* *}$ & $342.80 * *$ & $13.445^{* * *}$ & $26.87^{*}$ & $0.0018^{* * *}$ & $0.022342^{* *}$ & $0.000198^{* *}$ & $1.6848^{* * *}$ & 1.09499 \\
\hline SCA & 20 & $13.48^{* * *}$ & 2.25 & $46.68 * *$ & $2.371^{* *}$ & $172.56^{* * *}$ & $3560.1^{* * *}$ & $177.62^{* * *}$ & $231.13 * *$ & $13.07^{* * *}$ & $269.77 * *$ & $0.0019^{* * *}$ & $0.02035^{* * *}$ & $0.000391^{* * *}$ & $4.45436 * *$ & $2.1739 * *$ \\
\hline Error & 30 & 1.00 & 1.35 & 16.33 & 0.510 & 0.1448 & 366.95 & 35.064 & 51.041 & 0.3535 & 9.55 & 0.00008 & 0.00006 & 0.000001 & 0.08136 & 0.77683 \\
\hline \multicolumn{17}{|c|}{ Genetic components } \\
\hline$\sigma^{2}$ gca & & 1.065 & 0.211 & -0.927 & -0.099 & 19.254 & 94.158 & -6.082 & 4.447 & 0.378 & -3.632 & 0.0002 & 0.0001 & 0.0000025 & 0.2312 & 0.0762 \\
\hline$\sigma^{2}$ sca & & 2.777 & -0.256 & 15.274 & 1.0774 & 30.703 & 1395.5 & 75.11 & 77.453 & 4.554 & 124 & 0.0005 & 0.0082 & 0.000158 & 10874 & 0.3786 \\
\hline$\sigma^{2} \mathrm{gca} / \sigma^{2} \mathrm{sca}$ & & 0.384 & -0.824 & -0.061 & -0.092 & 0.627 & 0.067 & -0.081 & 0.057 & 0.083 & -0.029 & 0.400 & 0.012 & 0.016 & 0.000 & 0.201 \\
\hline$\sigma 2 \mathrm{~A}$ & & 4.260 & 0.844 & -3.708 & -0.396 & 77.016 & 376.632 & -24.328 & 17.788 & 1.512 & -14.528 & 0.001 & 0.000 & 0.000 & 0.925 & 0.305 \\
\hline 62D & & 11.108 & -1.024 & 61.096 & 4.310 & 122.812 & 5582.000 & 300.440 & 309.812 & 18.216 & 496.000 & 0.002 & 0.033 & 0.001 & 43496.000 & 1.514 \\
\hline h2(ns) & & 30.926 & 12.467 & -13.079 & -11.910 & 40.948 & 7.876 & -5.308 & 9.069 & 14.432 & -9.353 & 7.968 & 3.745 & 0.625 & 46.224 & 20.757 \\
\hline \multicolumn{17}{|l|}{$E_{2}:$ CS-II } \\
\hline GCA & 9 & $78.2721^{* * *}$ & $73.755 * *$ & 20.9032 & 0.11912 & 0.9205 & 65.1731 & 16.2659 & 54.7656 & $134.488^{* * *}$ & 4.076253 & $0.00186^{* * *}$ & $0.022556^{* * *}$ & $0.000198^{* *}$ & 2.123 & $1.386^{*}$ \\
\hline SCA & 20 & $13.795^{* * *}$ & $2.2312^{*}$ & $51.1851^{* *}$ & $2.83924 * *$ & $176.833 * *$ & $3915.12 * *$ & $193.9875^{* *}$ & $333.513^{* *}$ & $13.0775 * *$ & 254.3312 & $0.00168^{* * *}$ & $0.019547^{* * *}$ & $0.00039^{* * *}$ & $3.65876^{* * *}$ & $1.692^{* * *}$ \\
\hline Error & 30 & 0.88064 & 0.96505 & 14.5232 & 0.43312 & 17.9776 & 526.3379 & 57.3844 & 56.8828 & 0.36509 & 12.31574 & 0.000078 & 0.000094 & 0.000001 & 0.16528 & 0.549 \\
\hline \multicolumn{17}{|c|}{ Genetic components } \\
\hline$\sigma^{2}$ sca & & 2.888 & 0.2476 & 20.422 & 0.564 & 5.446 & 1457.8 & 75.26 & 95.77 & 4.5525 & 96.691 & 0.0005 & 0.0079 & 0.0001583 & 0.8313 & 0.125 \\
\hline$\sigma^{2}$ gca/ $\sigma^{2}$ sca & & 0.385 & 0.358 & -0.065 & 0.374 & 4.520 & 0.014 & -0.091 & 0.165 & 0.083 & 0.046 & 0.400 & 0.013 & 0.016 & 0.397 & 1.073 \\
\hline$\sigma 2 \mathrm{~A}$ & & 4.448 & 0.355 & -5.288 & 0.844 & 98.460 & 79.232 & -27.496 & 63.380 & 1.515 & 17.976 & 0.001 & 0.000 & 0.000 & 1.320 & 0.536 \\
\hline 62D & & 11.552 & 0.990 & 81.688 & 2.256 & 21.784 & 5831.20 & 301.04 & 383.080 & 18.210 & 386.764 & 0.002 & 0.032 & 0.001 & 3.325 & 0.500 \\
\hline h2(ns) & & 26.421 & 2.479 & -9.065 & 37.762 & 60.039 & 2.263 & -6.967 & 42.783 & 13.442 & 10.912 & 6.933 & 0.383 & 0.625 & 73.001 & 43.841 \\
\hline \multicolumn{17}{|l|}{$\mathrm{E}_{3:}$ CS-III } \\
\hline GCA & 9 & $74.7999 * *$ & $70.1163^{* * *}$ & 10.6922 & 0.254 & 2.8315432 & $310.1801^{* *}$ & $26.998^{* * *}$ & 88.2691 & $13.45041^{* *}$ & 5.358101 & $0.001545^{* * *}$ & $0.02236^{* * *}$ & $0.000199^{* * *}$ & $1.819^{* *}$ & $1.365^{*}$ \\
\hline SCA & 20 & $15.0953 * *$ & $2.49531 * *$ & 64.3968 & 2.371 & 170.12143 & $479.5344^{* *}$ & $198.412^{* *}$ & $326.8023 * *$ & $13.07754 * *$ & $103.991^{* *}$ & $0.0018431 * *$ & $0.0193 * *$ & $0.000387 * *$ & $3.294 * *$ & $2.175^{* * *}$ \\
\hline Error & 30 & 0.73334 & 0.72311 & 9.77124 & 0.458789 & 11.83804 & 83.76560 & 21.69353 & 120.4268 & 0.364980 & 9.886743 & 0.000074 & 0.000134 & 0.000001 & 0.367 & 0.588 \\
\hline \multicolumn{17}{|c|}{ Genetic components } \\
\hline$\sigma^{2}$ gca & & 0.681 & 0.171 & 6.324 & 0.1434 & 19.74 & -37.62 & 17.069 & 22.248 & 0.3789 & 0.0435 & 0.0002 & 0.0001 & 0.0000005 & 0.2112 & 0.0763 \\
\hline$\sigma^{2}$ sca & & 4.242 & 0.284 & 7.579 & 0.0422 & 14.91 & 268.65 & 51.521 & 110.23 & 4.5525 & 38.96 & 0.0005 & 0.0077 & 0.000161 & 0.8125 & 0.3792 \\
\hline$\sigma^{2} \mathrm{gca} / \sigma^{2} \mathrm{sca}$ & & 0.161 & 0.602 & 0.834 & 3.398 & 1.324 & -0.140 & 0.331 & 0.202 & 0.083 & 0.001 & 0.400 & 0.013 & 0.003 & 0.260 & 0.201 \\
\hline$\sigma 2 \mathrm{~A}$ & & 2.724 & 0.684 & 25.296 & 0.574 & 78.960 & -150.480 & 68.276 & 88.992 & 1.516 & 0.174 & 0.001 & 0.000 & 0.000 & 0.845 & 0.305 \\
\hline 62D & & 16.968 & 1.136 & 30.316 & 0.169 & 59.640 & 1074.600 & 206.084 & 440.920 & 18.210 & 155.840 & 0.002 & 0.031 & 0.001 & 3.250 & 1.517 \\
\hline h2(ns) & & 16.598 & 5.009 & 72.098 & 46.790 & 57.512 & -39.161 & 28.222 & 47.342 & 12.935 & 0.201 & 8.388 & 0.388 & 0.129 & 48.399 & 20.531 \\
\hline
\end{tabular}

*Significant at $5 \%$ level; **Significant at $1 \%$ level of probability 
Table.3 GCA effects of the parents of crosses showing SCA effects for seed yield plant ${ }^{-1}$ under $E_{1}, E_{2}$ and $E_{3}$ in chickpea

\begin{tabular}{|c|c|c|c|c|}
\hline Environments & Cross combination & SCA effects & GCA effect of females parent & GCA effect of male parent \\
\hline \multirow[t]{7}{*}{$\mathrm{E}_{1}(\mathrm{CS}-\mathrm{I})$} & JG 130 x JG 97 & $25.430 * *$ & $1.370(\mathrm{~L})$ & $-2.870(L)$ \\
\hline & JG 14 x JG 97 & $11.280 * *$ & $10.400 * *(\mathrm{H})$ & $-2.870(L)$ \\
\hline & JG 315 x JG 97 & $9.700 * *$ & $-6.300 * *(\mathrm{H})$ & $-2.870(L)$ \\
\hline & Indira Chana-1 x JG 97 & $5.200 *$ & $1.340 \quad(\mathrm{~L})$ & $-2.870(L)$ \\
\hline & JG 11 x JG 97 & $4.800 * *$ & $-8.430 * *(\mathrm{H})$ & $-2.870(L)$ \\
\hline & JG 315 x ICCV 96029 & $3.300 * *$ & $-6.300 * *(\mathrm{H})$ & $1.600 *$ \\
\hline & Vaibhav x ICCV 96029 & $2.970 * *$ & $-7.300 * *(\mathrm{H})$ & $-2.870 \quad$ (L) \\
\hline \multirow[t]{5}{*}{$\mathrm{E}_{2}(\mathrm{CS}-\mathrm{II})$} & JG 130 x JG 97 & $23.650 * *$ & $-0.250(\mathrm{~L})$ & $-2.230(L)$ \\
\hline & JG 14 x JG 97 & $12.800 * *$ & $10.620 * *(\mathrm{H})$ & $-2.230(\mathrm{~L})$ \\
\hline & JG 315 x JG 97 & $8.390 * *$ & $-6.580 * *(\mathrm{H})$ & $-2.230(\mathrm{~L})$ \\
\hline & Indira chana-1 x JG 97 & $7.230 *$ & $1.550 \quad(\mathrm{~L})$ & $-2.230(L)$ \\
\hline & JG 315 x ICCV 96029 & $3.560 * *$ & $-6.580 * *(\mathrm{H})$ & $1.670 *(\mathrm{H})$ \\
\hline \multirow[t]{5}{*}{ E3(CS-III) } & JG 130 x JG 97 & $11.200 * *$ & $2.850(\mathrm{~L})$ & $0.420(\mathrm{~L})$ \\
\hline & JG 16 x JG 97 & $7.360 * *$ & $7.560 * *(\mathrm{H})$ & $0.420(\mathrm{~L})$ \\
\hline & JG 14 x JG 97 & $7.140 * *$ & $4.210 * *(\mathrm{H})$ & $0.420(\mathrm{~L})$ \\
\hline & JG 315 x JG 97 & $7.080 * *$ & $-2.650 *(\mathrm{H})$ & $0.420(\mathrm{~L})$ \\
\hline & JG 315 x ICCV 96029 & $4.490 * *$ & $-2.650 *(H)$ & $0.750(L)$ \\
\hline
\end{tabular}


Table.4 Top ranking per se performance and sca effects and heterosis of $\mathrm{F}_{1}$ 's and gca effects of the parents for seed yield plant ${ }^{-1}$ in chickpea

\begin{tabular}{|c|c|c|c|c|c|c|c|}
\hline \multirow{2}{*}{ Environments } & \multirow[t]{2}{*}{ Hybrids } & \multirow{2}{*}{$\begin{array}{c}\text { Per se } \\
\text { performance seed } \\
\text { yield per plant }(\mathrm{g})\end{array}$} & \multirow[t]{2}{*}{ sca effects } & \multirow[t]{2}{*}{ gca effect of female } & \multirow{2}{*}{$\begin{array}{c}\text { gca effect of } \\
\text { male }\end{array}$} & \multicolumn{2}{|c|}{ Heterosis (\%) } \\
\hline & & & & & & $\mathbf{R H}$ & HB \\
\hline \multirow[t]{6}{*}{$\mathrm{E}_{1}(\mathrm{CS}-\mathrm{I})$} & JG 130 x JG 97 & 71.30 & $25.430 * *$ & 1.370 & -2.870 & $113.154 * *$ & $100.450 * *$ \\
\hline & JG 14 x JG 97 & 56.00 & $11.280 * *$ & $10.400 * *$ & -2.870 & $47.504 * *$ & $25.561 * *$ \\
\hline & JG $315 \times$ JG 97 & 42.40 & $9.700 * *$ & $-6.300 * *$ & -2.870 & $43.171 * *$ & $35.334 * *$ \\
\hline & JG 11 x JG 97 & 34.30 & $4.800 * *$ & $-8.430 * *$ & -2.870 & $20.140 * *$ & 9.480 \\
\hline & JG 315 x ICCV 96029 & 29.10 & $3.300 * *$ & $-6.300 * *$ & $1.600 *$ & -0.157 & -11.173 \\
\hline & Indira Chana-1 x JG 97 & 28.10 & $5.200 *$ & 1.340 & -2.870 & -15.944 & -20.912 \\
\hline \multirow[t]{5}{*}{$\mathrm{E}_{2}(\mathrm{CS}-\mathrm{II})$} & JG $130 \times$ JG 97 & 66.55 & $23.650 * *$ & -0.250 & -2.230 & $40.351 * *$ & $35.959 * *$ \\
\hline & JG 14 x JG 97 & 55.25 & $12.800 * *$ & $10.620 * *$ & -2.230 & 7.153 & -9.091 \\
\hline & JG 315 x JG 97 & 37.65 & $8.390 * *$ & $-6.580 * *$ & -2.230 & $37.761 * *$ & $27.584 *$ \\
\hline & Indira chana-1 x JG 97 & 29.85 & $7.230 *$ & 1.550 & -2.230 & -4.921 & -10.306 \\
\hline & JG 315 x ICCV 96029 & 29.55 & $3.560 * *$ & $-6.580 * *$ & $1.670 *$ & 0.922 & -11.553 \\
\hline \multirow[t]{5}{*}{ E3(CS-III) } & JG 130 x JG 97 & 40.55 & $11.200 * *$ & 2.850 & 0.420 & $49.635^{*}$ & 42.361 \\
\hline & JG 14 x JG 97 & 41.75 & $7.140 * *$ & $4.210 * *$ & 0.420 & $94.915 * *$ & $76.923 * *$ \\
\hline & JG 315 x JG 97 & 36.65 & $7.080 * *$ & $-2.650 *$ & 0.420 & $77.255^{* *}$ & $73.846 * *$ \\
\hline & JG 16 x JG 97 & 32.65 & $7.360 * *$ & $7.560 * *$ & 0.420 & $62.931 *$ & 45.385 \\
\hline & JG 315 x ICCV 96029 & 26.05 & $4.490 * *$ & $-2.650 *$ & 0.750 & $82.500 * *$ & $75.200 * *$ \\
\hline
\end{tabular}

*\&**Significant at $\mathrm{P}=0.05 \& 0.01$ level of probability; $\mathrm{H}=$ High combining ability and L=Low combining ability $\mathrm{RH}=\mathrm{Relative}$ heterosis and $\mathrm{HB}$ $=$ Heterobeltiosis. 


\section{Specific combing ability}

Even though SCA effect does not contribute tangibly in the improvement of self-pollinated crops, except in situations where exploration of heterosis is feasible, best crosses are expected to generate transgrasive segregants which could be selected as potent homozygous lines.

Result of sca analysis revealed that some exhibited significant desirable sca estimates in all the environment for one or more characters whereas, for other trait they shared significant SCA in one or two environment. Hence, in order to draw some valid conclusions result of the crosses exhibited significant sca for the traits under all the environments have discussed. The hybrid Vaibhav x JG 97 exhibited desirable negative SCA for days to $50 \%$ flowering in all the three environments. The hybrid Vaibhav x ICCV 96029 exhibited desirable positive SCA in all the environments for 100 seed weight and seed volume. The hybrid Indira chana-1 x ICCV 96029 exhibited desirable negative SCA for days to $50 \%$ flowering and desirable positive SCA for swelling index and protein content in all the environments. The hybrid Indira Chana-1 x ICCV 96030 exhibited desirable positive SCA for pods plant $^{-1}, 100$ seed weight, seed volume and hydration capacity seed $^{-1}$ in all the three environments. The hybrid JG 315 x JG 97 exhibited significant positive SCA for harvest index seed yield plant $^{-1}$ and seed volume in all the three environments.

The hybrid JG 315 x ICCV 96029 showed positive desirable SCA for seed yield plant ${ }^{-1}$ in all the three environments.ie. $\mathrm{E}_{1}, \mathrm{E}_{2}$ and $\mathrm{E}_{3}$. The hybrid JG $11 \mathrm{x}$ ICCV 96029 exhibited desirable positive SCA for swelling index in all the three environments. The hybrid JG 11 x ICCV 96030 exhibited desirable positive SCA for 100 seed weight in all the three environments. The hybrid JG 14 x JG 97 exhibited positive significant desirable SCA for harvest index, 100 seed weight, seed yield plant $^{-1}$ and hydration index in all the three environments. The hybrid JG 16 x ICCV 96029 exhibited desirable negative SCA for days to $50 \%$ flowering whereas, it had desirable positive SCA for plant height, 100 seed weight and swelling index in all the environments. The hybrid JG 130 x JG 97 exhibited desirable positive SCA for pods plant $^{-1}$, biological, harvest index, 100 seed weight and seed yield plant ${ }^{-1}$ in all the three environments. The hybrid JG 130 x ICCV 96030 exhibited significant positive desirable SCA for hydration index in all the three environments. Similar finding were reported by Khan et al., (2006), Gupta et al., (2007) and Bhatt et al., (2013) for days to maturity. Jayalakshmi et al., (2009) and Naveed et al., (2012) for plant height. Sewak et al., (2012), Gadekar and Dodiya (2013) and Mishra et al., (2013) for primary branches plant ${ }^{-1}$ and Secondary branches plant ${ }^{-1}$. Bhardwaj et al., (2010) for pods plant $^{-1}$, Biological yield, harvest index, 100 seed weight and seed yield plant ${ }^{-1}$. Naveed et al., (2012)for harvest index, Sidramappa et al., (2008), Malik et al., (2011) and Mishra et al., (2013) for 100 seed weight and seed yield plant ${ }^{-1}$.

Per se performance seed yield plant ${ }^{-1}$ is the ultimate and most important traits presented in table 3. In the present investigations, the degree of heterosis for seed yield varied considerably. Out of 21 crossed 2 crosses (JG 130 x JG 97 and JG 315 x JG 97) exhibited significant positive mid and better parents heterosis in all three environments. However, the highest mean value was sown JG $130 \times \mathrm{JG}$ 97(71.30 $\left.\mathrm{g} \mathrm{plant}^{-1}\right)$ in $\mathrm{E}_{1}, 66.55 \mathrm{~g}_{\text {plant }}{ }^{-1}$ in $\mathrm{E}_{2}$ and $40.55 \mathrm{~g} \mathrm{plant}^{-1}$ in $\mathrm{E}_{3}$. The crosses JG 14 $\mathrm{x}$ JG 97 performed MP and BP parents heterosis in $\mathrm{E}_{1}$ and $\mathrm{E}_{3}$ and JG $315 \mathrm{x}$ ICCV 96029 performed positive MP and BP parents heterosis in $\mathrm{E}_{3}$ for high seed yield should be utilized for future hybridization programme 
Line $\mathrm{x}$ Tester analysis mean sum of square due to genotypes was highly significant for all the traits in $E_{1}, E_{2}$ and $E_{3}$. Analysis of variance for combining ability revealed that the variance due to gca were highly significant for all the characters in all the environments except for days to maturity in $\mathrm{E}_{1}$, plant height and primary branches plant ${ }^{-1}$ in $E_{1}, E_{2}$ and $E_{3}$, secondary branches, seed yield and harvest index in $E_{2}$ and $E_{3}$, pods plant ${ }^{-1}$ in $E_{1}$ and $E_{2}$, biological yield plant ${ }^{-1}$ in $\mathrm{E}_{2}$ and protein content in $\mathrm{E}_{1}$.

Similarly variance due to sca were highly significant for all the characters in all the environments except days to maturity in $E_{1}$, plat height, primary branches plant $^{-1}$ and secondary branches plant ${ }^{-1}$ in $E_{3}$, seed yield plant $^{-1}$ in $E_{2}$ indicated the importance of both additive and non-additive gene effect in their expression.

Per se performance seed yield plant $^{-1}$ is the ultimate and most important traits presented in table 4. In the present investigations, the degree of heterosis for seed yield varied considerably. Out of 21 crossed 2 crosses (JG 130 x JG 97 and JG 315 x JG 97) exhibited significant positive mid and better parents heterosis in all three environments. However, the highest mean value was sown JG $130 \times \mathrm{JG}$ 97(71.30 $\left.\mathrm{g} \mathrm{plant}^{-1}\right)$ in $\mathrm{E}_{1}, 66.55 \mathrm{~g} \mathrm{plant}^{-1}$ in $E_{2}$ and 40.55 g plant $^{-1}$ in $E_{3}$ for high seed yield should be utilized for future hybridization programme

\section{Acknowledgement}

The Author are great full to All India Coordinated Research Project on chickpea, Research cum Instructional farm, Department of Genetics and Plant Breeding, Indira Gandhi Krishi Vishwavidyalaya, Raipur for providing funding and field for the experiment and also thanks full to Major Advisor Dr. R.N. Sharma, Professor/ Principal Scientist, GPB at this university.

\section{References}

Anonymous, Descriptors for chickpea (Cicer arietinum L.). IBPGR/ ICRISAT/ ICARDA ROME. ICRISAT, Patancheru, India, 1993, pp.1-31.

Anonymous, Project Coordinator's Report, All India Coordinated Research Project on chickpea. Indian Institute Pulses Research, Kanpur, 2014, p.-29.

Bhardwaj, R., Sandhu, J.S. and Gupta, S.K., Gene action and combining ability estimates for yield and other quantitative traits in chickpea. (Cicer arietinum L.). Indian J. Agric. Sci., 2009, 79, 897-900.

Bhardwaj, R., Sandhu, J.S. and Singh, I., Heterosis in relation to combing ability in chickpea (Cicer arietinum L.). Crop Improvement, 2010, 37,126-132.

Bhatt, H., Anju, A. and Panwar, R.K., Genetic studies for yield contributing characters in chickpea (Cicer arietinum L.). Pantnagar J. Res., 2013, 11,214-218.

Gadekar, M.S. and Dodiya, N.S., Heterosis and combining ability analysis for yield and yield contributing traits in chickpea (Cicer arietinum L.). Legume Research, 2013, 36, 373-379.

Gupta, S.K., Sandhu, J.S. and Kumar, A., Line $\mathrm{x}$ Tester analysis in chickpea (Cicer arietinum L.). Crop Improvement, 2007, 34,170-172.

Jayalakshmi, V., Reddy, C.K.K. and Reddy, M.S., Heterosis and combining ability in chickpea under moisture stress condition in chickpea (Cicer arietinum L.). J. Food Legumes, 2009, 22, 56-58.

Kempthorne, O., An introduction to genetic statistics, New York. John Wiley and Sons, 1957, $2^{\text {nd }}$ ed; London: Chapam and Hall, Ltd.

Khan, H., Ahmad, F. and Iqbal, N., Genetic variability and correlations among quantitative traits in gram. Sarhad J. Agric., 2006, 22: 55-59. 
Malik, S. R., Saleem, M., Iqubal, U., Zahid, M.A. Baksh, A and Iqubal, S.M., Genetic analysis of physiochemical traits in chickpea (Cicer arietinum L.) seeds. Int. J. Agric. Bio., 2011, 13, 1033-1036.

Mishra, N., Awasthi N.C. and Chaturvedi, S.K., Heterosis and inbreeding depression in wide crosses of chickpea (Cicer arietinum L.). Current Advances in Agric. Sci., 2013, 5, 23-26.

Monpara, B.A. and Gaikwad S.R., Combining high seed number and weight to improve seed yield potential of chickpea (Cicer arietinum L.) J. African Crop Sci., 2014, 22, 1-7.

Monpara, B.A., and Dhameliya, H.R., Genetic behaviour of earliness related traits and seed yield in chickpea (Cicer arietinum L.). Pakistan J. Biological Sci., 2013, 16, 955-959.
Naveed, M.T., Ali, Q., Saeed, U. and Babar. H., Combining ability analysis for various quantitative traits in chickpea (Cicer arietinum L.). IJBPAS, 2012, 1, 503-511.

Sewak, S., Iquebal, S.M., Singh, M.A., Solanki, N.P. and Sarika R.K., Genetic diversity studies in chickpea (Cicer arietinum L.) germplasm. J. Food Legumes, 2012, 25, 31-36.

Sidramappa, S., Patil, A. Salimath P.M. and Kajjidoni, S.T., Genetic variation for productivity and its related traits in recombinant inbred lines population of Chickpea. Karnataka J. Agric. Sci., 2008, 21, 488- 490.

Verma, P. and Waldiya, R.S., Diallel analysis for nodulation and yield contributing traits in chickpea (Cicer arietinum L.). J. Food Legumes, 2010, 23, 117-120.

\section{How to cite this article:}

Johnson, P.L., R.N. Sharma and Nanda, H.C. 2019. L X T Analysis of Yield Characters in Chickpea (Cicer arietinum L.) under Rice Based Cropping System. Int.J.Curr.Microbiol.App.Sci. 8(06): 1640-1651. doi: https://doi.org/10.20546/ijcmas.2019.806.196 